\title{
TRACER STUDY FAKULTAS EKONOMI UNIVERSITAS NEGERI JAKARTA
}

\section{DARMA RIKA S. * , ACHMAD FAUZI* , HENRY ERYANTO* \& R.R.PONCO DEWI K. ${ }^{*}$}

\begin{abstract}
This study was conducted to identify the competencies of graduates FE UNJ waiting times based upon the profile of the work, the suitability of the first areas of work, salary and perceptions about the competence of the alumni corporation. This research is a qualitative study and the population are alumnies of the Faculty of Economics who working in government agencies, private and entrepreneur and graduated from the period 2011/2012 to $2012 / 2013$. Sample of the population is set at $10 \%$ of the total population, and using a technique comvenience sampling ( non probability sampling ). The data used in this study is primary data obtained from interviews and use the questionnaire instrument. Data were analyzed using descriptive statistics by looking at the frequency distribution and the average of respondents's answers regarding the competence of graduates of the Faculty of Economics UNJ. 92.8 $\%$ of alumni of the Faculty of Economics working as employees of the company, $5.8 \%$ be a teacher, others go to college and as entrepreneurs. The average waiting time for alumnies FE UNJ only takes waited less than 6 months to get a job. The level of salary received at the time of the first alumni of work varies with an average of 2-3 million by $49 \%$ and between 3 million and above by $23 \%$. The level of compliance competencies and job average amounted to $77 \%$ of alumni and competence of alumni based on the user 's perception was expressed by $71 \%$ of alumni FE UNJ have a good competence.
\end{abstract}

Keywords: competencies, profile, Faculty of Economic

\section{PENDAHULUAN}

Pendidikan tinggi di Indonesia merupakan tahap pendidikan formal

Darma Rika S. , Achmad Fauzi, Henry Eryanto \& R.R.Ponco Dewi K. adalah dosen Fakultas Ekonomi Universitas Negeri Jakarta. terakhir yang siap mendidik dan mempersiapkan seseorang untuk menjadi pelaku professional dalam bidang keahlian tertentu yang diperlukan oleh dunia kerja.Dunia pendidikan tinggi dewasa ini 
mengalami perkembangan yang sangat pesat. Hal ini ditandai dengan semakin banyak didirikan perguruan tinggi baru dan juga semakin banyak dibuka program studi baru oleh universitas maupun institut yang ada di Indonesia. Berdasarkan data per tanggal 7 Oktober 2013 diketahui bahwa di wilayah Kopertis III Jakarta saja terdapat 50 Universitas swasta, 12 institut, 141 sekolah tinggi, 132 akademi dan 8 politeknik (Kopertis3.or.id). Selain itu kebijakan pemerintah juga secara resmi mengijinkan pihak asing mendirikan perguruan tinggi di Indonesia menuntut pendidikan tinggi harus mampu bersaing secara global.

Pendidikan tinggi juga merupakan pendidikan yang berada di garis depan dalam menghadapi perubahan lingkungan. Perubahan lingkungan perlu diakomodir oleh perguruan tinggi agar perguruan tinggi tetap mampu berperan sebagai penyedia intellectual asset bagi penggunanya (user).

Perubahan Institut Keguruan dan Ilmu Pendidikan (IKIP) menjadi Universitas pada 4 Agustus 1999 berdasarkan Keputusan Presiden Nomor 93 tahun 1999, hakikatnya bukan merupakan perubahan/perkembangan karena inisiatif dan dinamika internal sivitas akademika, melainkan merupakan bagian dari kebijaksanaan nasional dalam mengembangkan Sistem Pendidikan Nasional dan perubahan yang terjadi karena tuntutan pasar kerja yang sudah semakin tinggi.

Sebagai dampak globalisasi, pendidikan tinggi saat ini dituntut untuk memenuhi kebutuhan, keinginan dan harapan masyarakat.Karena itu Universitas Negeri Jakarta (UNJ), sebagai salah satu Perguruan Tinggi Negeri di Indonesia, juga dituntut untuk mampu memberikan pelayanan pendidikan berkualitas. Selain perubahan IKIP Jakarta menjadi UNJ, tuntutan akan pelayanan pendidikan berkualitas disikapi dengan lahirnya Fakultas Ekonomi (FE) UNJ yang sebelumnya merupakan salah satu jurusan di Fakultas IImu Sosial UNJ.

FE UNJ perlu menyadari tuntutan pasar tenaga kerja yang semakin tinggi dan peningkatan persaingan tenaga kerja yang semakin ketat. Hal ini perlu disikapi dengan melakukan perubahanperubahan secara terus menerus (continous improvement) dalam menjalankan sistem organisasi (input-proses-output).Daya saing lulusan FE UNJ sangat ditentukan oleh kompetensi yang 
dimilikinya.Terkait

dengan

kompetensi lulusan, perubahan terus

menerus perlu dilakukan di bidang akademik khususnya.

Seiring dengan meningkatkan pelayanan pendidikan yang berkualitas maka perubahan dalam hal pelayanan kemahasiswaan menuju ke arah yang lebih baik pun harus ditingkatkan agar FE UNJ dapat memberikan yang terbaik untuk mahasiswa.Ketika mahasiswa merasakan pelayanan pendidikan dan kemahasiswaan yang baik berimbas kepada adanya perubahan perilaku dan peningkatan kompetensi mereka.

\section{Perumusan Masalah}

Upaya memberikan pelayanan pendidikan dan pelayanan kemahasiswaan yang berkualitas bertujuan untuk meningkatkan kualitas lulusan sehingga memiliki daya saing dan cepat diserap dunia kerja.Lulusan yang berkualitas dapat dilihat dari relevansi antara kompetensi lulusan dengan kebutuhan penggunanya.Salah satu tahapan kegiatan yang dilakukan untuk mengetahui antara kompetensi Iulusan dengan kebutuhan penggunanya adalah studi jejak rekam (Tracer Study). Hal ini juga ditunjang dengan mewujudkan pendataan yang berkelanjutan, pemantauan dan evaluasi mutu lulusan, peningkatan daya saing lulusan serta mewujudkan Iulusan Fakultas Ekonomi yang akuntabel.

Berdasarkan latar belakang penelitian diatas dirumuskan masalah sebagai berikut: "Bagaimana kompetensi lulusan FE UNJ berdasarkan profil lulusan tentang lama studi, waktu tunggu bekerja, kesesuaian bidang pekerjaan dan gaji awal) dan pelayanan kemahasiswaan terhadap Iulusan selama menjadi mahasiswa?"

\section{Tujuan Penelitian} adalah

Adapun tujuan penelitian ini

1. Untuk mengidentifikasi kompetensi lulusan FE UNJ berdasarkan profil lulusan tentang waktu tunggu bekerja, kesesuaian bidang pekerjaan dan gaji awal.

2. Untuk mengetahui kompetensi yang diperlukan guna menunjang tersedianya tenaga kerja yang siap pakai.

3. Untuk mengetahui bagaimana layanan kemahasiswaan civitas akademika FE UNJ terhadap Iulusan FE UNJ selama menjadi mahasiswa . 


\section{Kontribusi Penelitian}

Hasil penelitian ini diharapkan dapat memberikan kontribusi bagi:

1. Ilmu Pengetahuan, memperkaya pemahaman mengenai tracer study.

2. Lembaga, dalam hal ini adalah:

a. sebagai bahan masukan dalam rangka penyusunan kebijakan pengembangan dan peningkatan kualitas pendidikan dan kualitas pelayanan di FE UNJ.

b. sebagai upaya meningkatkan kesiapan lulusan dalam penyediaan tenaga kerja siap kerja, guna memenuhi permintaan pasar kerja sebagai tenaga kerja yang memiliki kompetensi yang dibutuhkan didunia industri/user.

\section{TINJAUAN PUSTAKA}

\section{Profil Fakultas Ekonomi UNJ}

Fakultas Ekonomi Universitas Negeri Jakarta mulai berdiri sejak tanggal 2 Mei 2005 dengan dikuatkan oleh SK Rektor UNJ Nomor: 297/SP/2005 sebagai tindak lanjut dari Surat Direktorat Jenderal Pendidikan Tinggi Nomor: 1193/D/T/2005 Perihal Pembukaan Fakultas Ekonomi tertanggal 11 April 2005. Peresmian FE UNJ dipimpin langsung oleh Rektor UNJ, Prof. Dr. Sutjipto pada hari Selasa (03 Mei 2005) lima tahun yang lalu dengan dihadiri sejumlah pejabat dan civitas akademika UNJ.

Fakultas Ekonomi UNJ terdiri dari tiga jurusan, yaitu Jurusan Akuntansi, Jurusan Manajemen, Jurusan Ekonomi dan Administrasi. Selain ketiga jurusan tersebut fakultas ini juga membawahi lima Program Studi (Prodi) yang terdiri dari program sarjana (S1) dan program diploma tiga (D3). Program Strata-1, meliputi Program Studi Manajemen (S1), Program Studi Pendidikan Ekonomi dengan konsentrasi Pendidikan Administrasi Perkantoran, Pendidikan Akuntansi, dan Pendidikan Ekonomi Koperasi, serta Program Studi Pendidikan Tata Niaga.Sedangkan program D3 meliputi: D3 Akuntansi, D3 Pemasaran dan D3 Sekretari.

Fakultas

Ekonomi mewajibkan seluruh mahasiswa mulai angkatan 2006/2007 memiliki skor TOEFL minimal 450 dan selanjutkan akan ditingkatkan pada masa mendatang. Fakultas Ekonomi telah menetapkan Program Studi Akuntansi S1 dan Program Studi Manajemen S1 membuka layanan kelas billingual. Untuk tahun 2013, di Program 
Studi Pendidikan Administrasi Perkantoran S1, Program Studi Pendidikan Tata Niaga S1 dan P rogram Studi D3 Sekretari juga membuka layanan kelas bilingual.

\section{Visi dan Misi Fakultas Ekonomi}

\section{a. Visi}

Menjadi fakultas terbaik, penghasil SDM profesional, berdaya saing tinggi di bidang kependidikan dan non kependidikan yang memiliki wawasan global serta menguasai ilmu pengetahuan dan teknologi dibidang ekonomi, administrasi, manajemen, dan akuntansi, dalam membangun masyarakat Indonesia yang maju, demokratis dan sejahtera berdasarkan Pancasila.

\section{b. Misi}

1. Melaksanakan

sistem pembelajaran yang profesional dengan terus mengembangkan berbagai sumber daya pembelajaran dan relevansi muatan kurikulum dengan kebutuhan dunia bisnis yang diimbangi dengan akhlak mulia, wawasan wirausaha dan wawasan global.

2. Melaksanakan peningkatan mutu pendidikan, penelitian dan pengabdian masyarakat yang profesional dengan terus menerus mengembangkan sumber daya staf akademik, sarana prasarana dan pemantapan sistem kelembagaan.

3. Melaksanakan penelitian dan pengembangan dalam bidang pendidikan dan pengajaran serta dunia bisnis.

4. Menjalin kerjasama dengan instansi pemerintah dan dunia bisnis dalam dan luar negeri sebagai mitra kerjasama dibidang pendidikan dan bisnis yang saling menguntungkan.

\section{c. Tujuan Fakultas Ekonomi}

1. Meningkatkan daya tampung dan peluang belajar ilmu ekonomi bagi generasi muda Indonesia.

2. Menyelenggarakan pendidikan, penelitian dan pengabdian kepada masyarakat untuk mendukung penyiapan tenaga kerja yang kompeten.

3. Menghasilkan Sarjana Pendidikan, Sarjana Ekonomi dan Ahli Madya yang memiliki kemampuan akademik dan profesionalitas yang sesuai dengan kebutuhan dunia kerja. 


\section{Pengertian Kompetensi}

Menurut Kamus Kompetensi LOMA (1998), kompetensi didefinisikan sebagai aspek-aspek pribadi dari seorang pekerja yang memungkinkan dia untuk mencapai kinerja yang superior. Aspek-aspek pribadi ini termasuk sifat, motifmotif, sistem nilai, sikap, pengetahuan, dan ketrampilan. Kompetensi-kompetensi akan mengarahkan tingkah laku. Sedangkan tingkah laku akan menghasilkan kinerja.

Berdasarkan definisi tersebut maka dapat disimpulkan bahwa tidak semua aspek-aspek pribadi dari seseorang pekerja itu merupakan kompetensi. Hanya aspek-aspek pribadi yang mendorong dirinya untuk mencapai kinerja yang superiorlah yang merupakan kompetensi yang dimilikinya. Selain itu, juga dapat disimpulkan bahwa kompetensi akan selalu terkait dengan kinerja yang superior.

Model kompetensi didefinisikan sebagai suatu rangkaian kompetensi yang penting bagi kinerja yang superior dari sebuah pekerjaan atau sekelompok pekerjaan. Model kompetensi ini memberikan sebuah peta yang membantu seseorang memahami cara terbaik mencapai keberhasilan dalam pekerjaan atau memahami cara mengatasi suatu situasi tertentu (LOMA,s Competency Dictionary, 1998).

Menurut Kamus Kompetensi LOMA (1998) aplikasi dari model kompetensi pada sistem Manajemen Sumber Daya Manusia muncul pada area-area berikut :

1. Staffing. Strategi-strategi rekrutmen dan tes-tes yang digunakan untuk seleksi didasarkan atas kompetensikompetesi kritikal dari pekerjaan

2. Evaluasi Kinerja. Penilaian kinerja dari pekerja didasarkan atas kompetensikompetensi yang dikaitkan dengan target -target yang penting dari organisasi

3. Pelatihan. Program-program pelatihan dirancang untuk menjembatani kesenjangan antara kompetensi yang dimiliki pekerja dan kompetensi yang diharapkan dimiliki pekerja

4. Pengembangan. Para pekerja pertama kali diukur untuk mengenali kesenjangan kompetensinya; kemudian mereka dibimbing untuk membuat rencana-rencana pengambangan untuk 
menutupi kesenjangan yang ada

5. Reward \& Recognition. Para pekerja diberikan kompensasi untuk prestasi-prestasi dan tingkah laku-tingkah laku yang mencerminkan tingkat ketrampilan mereka pada kompetensi-kompetensi kunci.

Hal tersebut di atas sejalan dengan pendapat dari Michael Amstrong dalam Handbook of Human Resources Management Practice (2001) yang mengemukakan bahwa penerapan kompetensi dalam Manajemen SDM dilakukan dalam proses rekrutmen dan seleksi, assessment centres, manajemen kinerja, pengembangan SDM, dan manajemen imbal jasa.

Aplikasi dari model-model kompetensi di perusahaan dapat memberikan manfaat dalam meningkatkan sistem Manajemen Sumber Daya Manusia yang ada di dalam perusahaan, seperti yang diungkapkan oleh Lucia dan Lepsinger (1999) berikut :

1. Seleksi

a. Memberikan gambaran yang lebih lengkap mengenai persyaratan-persayaratan jabatan

b. Meningkatkan kemungkinan untuk merekrut pekerja yang akan berhasil di dalam pekerjaannya.

c. Meminimalkan investasi (waktu dan uang) pada pekerja yang mungkin tidak memenuhi harapan perusahaan.

d. Memastikan proses wawancara yang lebih sistematis.

e. Membantu membedakan kompetensi-kompetensi yang dapat dilatihkan dan kompetensi-kompetensi yang sulit untuk dikembangkan.

2. Pelatihan dan Pengembangan

a. Memungkinkan pekerja untuk memusatkan perhatian pada ketrampilan, pengetahuan, dan karakteristikkarakteristik yang mempunyai dampak terbesar terhadap efektifitasnya

b. Memastikan bahwa kesempatan-kesempatan untuk melakukan pelatihan dan pengembangan berjalan selaras dengan sistem nilai dan strategistrategi organisasi

c. Memaksimalkan efektifitas dari waktu dan dana yang 
digunakan untuk melakukan pelatihan dan pengembangan

d. Memberikan sebuah kerangka untuk melakukan proses bimbingan dan pemberian umpan balik yang berkelanjutan

3. Penilaian Kinerja

a. Memberikan pemahaman bersama tentang hal-hal yang akan dimonitor dan diukur

b. Memusatkan perhatian dan mendorong proses diskusi tentang penilaian kinerja

c. Memusatkan perhatian dalam mendapatkan informasi tentang tingkah laku pekerja dalam pekerjaan

4. Perencanaan Karir/suksesi

a. Menjelaskan tentang ketrampilan-ketrampilan, pengetahuan dan

karakteristik-karakteristik yang diperlukan oleh suatu pekerjaan/peran

b. Memberikan metode untuk mengukur kesiapan dari calon pemegang jabatan atas peran yang akan dipegangnya

c. Memusatkan perhatian dari rencana pelatihan dan pengembangan pada kompetensi - kompetensi yang belum dimiliki oleh calon pemegang jabatan

d. Memungkinkan organisasi untuk melakukan pembandingan (benchmark) diantara sejumlah karyawan potensial yang prestasinya sangat baik.

\section{Teori Pasar Kerja}

Pasar kerja adalah seluruh aktivitas pelaku-pelaku ekonomi yang mempertemukan pencari kerja dan kesempatan kerja. Pelaku-pelaku tersebut terdiri dari: (1) pengusaha yang membutuhkan pekerja, dan (2) pencari kerja yang membutuhkan pekerjaan.

Proses interaksi keduanya membutuhkan waktu yang lama karena baik pencari kerja maupun kesempatan kerja tidak homogen dan informasi mengenai keduanya sangat terbatas. Pencari kerja ingin memperoleh pekerjaan dengan kondisi yang paling baik dan pengusaha ingin mencari pekerja yang paling cocok untuk mengisi lowongan.

Di dalam pasar kerja terjadi proses penempatan atau hubungan kerja melalui penyediaan dan permintaan tenaga kerja. Proses ini 
lebih lanjut dijelaskan dalam teori penawaran dan permintaan tenaga kerja.

Penawaran suatu komoditi adalah hubungan antara harga dan kuantitas. Sehubungan dengan tenaga kerja, penawaran adalah hubungan antara tingkat upah dengan jumlah tenaga kerja yang siap disediakan oleh para pemilik tenaga kerja. Namun, dalam menawarkan tenaganya, seorang pekerja dihadapkan pada kendala kelangkaan waktu. Secara rasional seorang pekerja harus membuat pilihan dalam pengguanan waktunya antara bekerja dan waktu istirahat (leisure).

Permintaan terhadap tenaga kerja merupakan permintaan tak langsung. Maksudnya, tenaga kerja dipekerjakan oleh perusahaan dengan tujuan untuk digunakan dalam menghasilkan barang-barang yang akan mereka jual (Sukirno, 2000). Dengan kata lain, pertambahan permintaan pengusaha terhadap tenaga kerja tergantung dari pertambahan permintaan masyarakat terhadap barang yang diproduksinya. Oleh karena itu permintaan akan tenaga kerja merupakan permintaan turunan.

Fungsi permintaan tenaga kerja biasanya didasarkan kepada teori neoklasik, dimana pada ekonomi pasar diasumsikan bahwa seorang pengusaha tidak dapat mempengaruhi harga (price taker). Dalam hal memaksimalkan laba, pengusaha hanya dapat mengatur berapa jumlah karyawan yang dapat dipekerjakan (Simanjuntak, 1985).

\section{Teori Kualitas Pelayanan}

Kualitas merupakan suatu kondisi dinamis yang berpengaruh dengan produk, jasa, manusia, proses dan lingkungan yang memenuhi atau melebihi harapan (Tjiptono, 2001). Sehingga definisi kualitas pelayanan dapat diartikan sebagai upaya pemenuhan kebutuhan dan keinginan konsumen serta ketepatan penyampaiannya dalam mengimbangi harapan konsumen (Tjiptono, 2007).

Kualitas pelayanan (service quality) dapat diketahui dengan cara membandingkan persepsi para konsumen atas pelayanan yang nyata-nyata mereka terima / peroleh dengan pelayanan yang sesungguhnya mereka harapkan / inginkan terhadap atribut-atribut pelayanan suatu perusahaan. Jika jasa yang diterima atau dirasakan (perceived service) sesuai dengan 
yang diharapkan, maka kualitas pelayananan dipersepsikan baik dan memuaskan, jika jasa yang diterima melampaui harapan konsumen, maka kualitas pelayanan dipersepsikan sangat baik dan berkualitas.Sebaliknya jika jasa yang diterima lebih rendah daripada yang diharapkan, maka kualitas pelayanan dipersepsikan buruk.

Menurut Kotler (2002:83) definisi pelayanan adalah setiap tindakan atau kegiatan yang dapat ditawarkan oleh suatu pihak kepada pihak lain, yang pada dasarnya tidak berwujud dan tidak mengakibatkan kepemilikan apapun. Produksinya dapat dikaitkan atau tidak dikaitkan pada satu produk fisik.Pelayanan merupakan perilaku produsen dalam rangka memenuhi kebutuhan dan keinginan konsumen demi tercapainya kepuasan pada konsumen itu sendiri.Kotler juga mengatakan bahwa perilaku tersebut dapat terjadi pada saat, sebelum dan sesudah terjadinya transaksi. Pada umumnya pelayanan yang bertaraf tinggi akan menghasilkan kepuasan yang tinggi serta pembelian ulang yang lebih sering. Kata kualitas mengandung banyak definisi dan makna, orang yang berbeda akan mengartikannya secara berlainan tetapi dari beberapa definisi yang dapat kita jumpai memiliki beberapa kesamaan walaupun hanya cara penyampaiannya saja biasanya terdapat pada elemen sebagai berikut:

1. Kualitas meliputi usaha memenuhi atau melebihkan harapan pelanggan.

2. Kualitas mencakup produk, jasa, manusia, proses dan lingkungan

3. Kualitas merupakan kondisi yang selalu berubah.

Dari definisi-definisi tentang kualitas pelayanan tersebut dapat diambil kesimpulan bahwa kualitas pelayanan adalah segala bentuk aktivitas yang dilakukan oleh perusahaan guna memenuhi harapan konsumen.Pelayanan dalam hal ini diartikan sebagai jasa atau service yang disampaikan oleh pemilik jasa yang berupa kemudahan, kecepatan, hubungan, kemampuan dan keramahtamahan yang ditujukan melalui sikap dan sifat dalam memberikan pelayanan untuk kepuasan konsumen.

Kualitas pelayanan (service quality) dapat diketahui dengan cara membandingkan persepsi para konsumen atas pelayanan yang nyata-nyata mereka terima / peroleh dengan pelayanan yang sesungguhnya mereka harapkan/inginkan terhadap 
atribut-atribut pelayanan suatu perusahaan. Hubungan antara produsen dan konsumen menjangkau jauh melebihi dari waktu pembelian ke pelayanan purna jual, kekal abadi melampaui masa kepemilikan produk. Perusahaan menganggap konsumen sebagai raja yang harus dilayani dengan baik, mengingat dari konsumen tersebut akan memberikan keuntungan kepada perusahaan agar dapat terus hidup.

\section{METODOLOGI PENELITIAN}

\section{Rancangan Penelitian}

Penelitian ini merupakan studi kualitatif yang bertujuan untuk mengetahui kompetensi lulusan FE UNJ disemua jurusan yaitu jurusan Ekonomi dan Administrasi, jurusan Akuntansi dan Jurusan Manajemenberdasarkan profil mengenai waktu tunggu bekerja, kesesuaian bidang pekerjaan, posisi pekerjaan sekarang, gaji awal dan persepsi perusahaan tempat bekerja terhadap kemampuan alumni dan mengetahui layanan kemahasiswaan terhadap lulusan selama menjadi mahasiswa.

\section{Populasi dan sampel}

Populasi penelitian ini adalah alumni Fakultas Ekonomi dari semua jurusan baik yang bekerja pada instansi pemerintah, swasta maupun wirausaha yang lulus dari periode 2011/2012 sampai 2012/2013. Dari populasi tersebut ditetapkan sampel minimal sebesar $10 \%$ dari jumlah populasi.

\section{Teknik Pengambilan Sampel}

Sampel dalam penelitian ini adalah alumni semua jurusan di Fakultas Ekonomi,tekni pengambilan sampel menggunakan teknik convenience sampling (non probability sampling). Alasan pemilihan teknik pengambilan sampel ini karena elemen populasi yang dijadikan sampel adalah yang paling mudah dan paling cepat ditemui. Hal ini dilakukan untuk mengantisipasi adanya kemungkinan database alumni yang belum diperbaharui (up date).

\section{Sumber Data}

Data yang digunakan dalam penelitian ini adalah data primer yaitu data yang diperoleh secara langsung dari responden melalui wawancara atau dengan menggunakan instrumen kuisioner. Selain data primer juga digunakan data sekunder yaitu data yang dikumpulkan oleh pihak lain (FE UNJ dan BAAK UNJ), yang dalam 
hal ini peneliti menggunakan data berupa database lulusan yang ada di Bagian Kemahasiswaan dan Alumni Fakultas.

\section{Teknik Pengumpulan Data}

Data primer diperoleh dengan cara:

1. Wawancara atau interview

Pengumpulan data primer dilakukan dengan wawancara langsung terhadap responden melalui telepon atau tatap muka langsung.

2. Menggunakan instrumen kuisioner

Data primer diperoleh dengan memberikan kuisioner melalui email, faksimili atau dengan pengisian langsung.

\section{Analisis Data Tracer Study}

Data yang telah diperoleh selanjutnya akan dianalisis dengan menggunakan statistik deskriptif yaitu dengan melihat distribusi frekuensi dan distribusi frekuensi relatif serta rata-rata jawaban responden mengenai kompetensi lulusan FE UNJ baik dari jurusan Ekonomi dan Administrasi jurusan Akuntansi maupun jurusan manjemen
Laporan tracer study memantau dan mengidentifikasi beberapa hal sebagai berikut:

- Daya saing lulusan yang ditunjukkan melalui waktu tunggu mendapatkan pekerjaan pertama, keberhasilan lulusan berkompetisi dalam seleksi dan gaji yang diperoleh.

- Relevansi

(kesesuaian) pendidikan lulusan ditunjukkan melalui profil pekerjaan (macam dan tempat pekerjaan), relevansi pekerjaan dengan background pendidikan, manfaat mata kuliah yang diprogram dalam pekerjaan, saran lulusan untuk perbaikan kompetensi lulusan.

- Korelasi antara kegiatan ekstrakurikuler lulusan selama studi dan daya saing lulusan.

- Kendala dan hambatan yang dihadapi solusi yang diusulkan proses tracer study dan saran perbaikan proses dapat menjadi pertimbangan tim berikutnya.

- Persepsi alumni tentang layanan kemahasiswaan selama menjadi mahasiswa (mulai dari kegiatan MPA, beasiswa, kegiatan organisasi kemahasiswaan, lomba yang diikuti dan lannnya). 


\section{ANALISIS DATA}

Pada bab ini peneliti akan menjabarkan data-data jejak rekam yang berhasil dikumpulkan dari alumni selama 6 bulan, dari bulan April - September 2013. Data yang disajikan berupa profil alumni Fakultas Ekonomi baik dari Jurusan Ekonomi dan Administrasi (EA),Jurusan Manajemen dan Jurusan Akuntansi di Universitas Negeri Jakarta, dimana untuk jurusan Ekonomi dan Administrasi terbagi dalam 3 program studi, yaitu Pendidikan Tata Niaga, D3 Sekretari dan Pendidikan Ekonomi yang terdiri dari 3 konsentrasi yaitu, pendidikan ekonomi dan koperasi, pendidikan administrasi perkantoran, dan pendidikan akuntansi. Jurusan manajemen terbagi menjadi dua program studi yaitu D3 Pemasaran dan S1 Manajemen. Serta jurusan Akuntansi yang terbagi menjadi dua prodi yaitu prodi S1 Akuntansi dan D3 Akuntansi.dengan periode kelulusan dimulai dari periode 2011/2012 - periode 2012/2013.

Ada 3 indikator yang digunakan untuk melihat kompetensi alumni Jurusan Ekonomi dan Administrasi yaitu jenis pekerjaan, lama waktu menunggu, dan tingkat penghasilan.Oleh karena itu disajikan data profile untuk ketiga indikator tersebut pada penjelasan berikut. Selain itu juga di akhir bab disajikan beberapa kesulitan dalam beradaptasi dengan lingkungan kerja yang dialami oleh responden, dan saran yang dikemukakan oleh responden untuk pengembangan kurrikulum Fakultas Ekonomi Universitas Negeri Jakarta.

\section{Karakteristik Data}

Data yang masuk dan ikut berpartisipasi dari alumni Fakultas Ekonomi Universitas Negeri Jakarta selama enam bulan penelitian tersaji dalam tabel 4.1 .

Tabel 4.1

Rekapitulasi Data Alumni Berdasarkan Jurusan

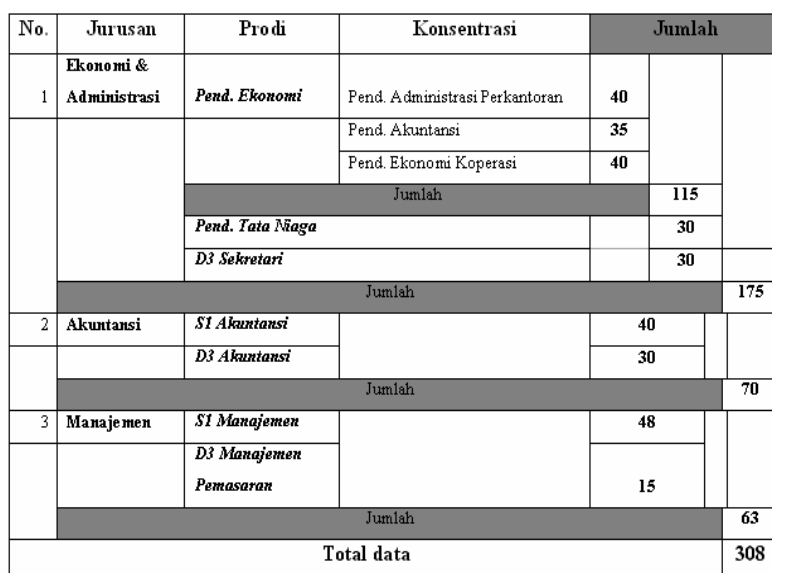

Dari tabel diketahui bahwa total alumni yang ikut berpartisipasi dalam program tracer sebanyak 308 orang, yang terbagi dalam 3Jurusan, dan dari periode 2011/2012 dan 2012/2013 baik 
untuk alumni yang lulus di semester ganjil maupun genap di setiap periode kelulusan. Alumni jurusan ekonomi dan administrasi tercatat sebagai responden yang paling banyak berpartisipasi, yaitu sebanyak 175 alumni, atau sebesar 56,8\% dari total responden yang masuk, sedang jurusan manajemen, paling sedikit partisipasi alumninya yaitu sebanyak 63 alumni, atau 20\% dari total responden. Akan tetapi apabila dilihat dariprogram studi, maka alumni dari program studi maka prodi pendidikan ekonomilah yang paling banyak berpartisipasi, yaitu sebesar 115 alumni, atau $37 \%$ dari total responden yang masuk dari semua program studi.

\section{Profile Pekerjaan Alumni Profile Pekerjaan Alumni Per Jurusan}

Alumni Fakultas Ekonomi Universitas Negeri Jakarta bekerja pada berbagai bidang, tidak sekedar menjadi tenaga pengajar, akan tetapi juga banyak yang bekerja di perusahaan, sebagai karyawan dan ada juga yang berwirausaha. Dari total 308 responden, dapat dihitung perbandingan persentase alumni yang bekerja sebagai guru, karyawan, dan wirausaha, dapat dilihat pada tabel 4.2 .
Jumlah total alumni yang berprofesi sebagai guru ada 18 orang, atau 5,8\% dari total responden, sedang alumni yang berprofesi sebagai karyawan ada 286 orang, atau 92,8\% dari total responden. Angka yang memprihatinkan ditunjukkan oleh jumlah alumni yang berwirausaha hanya 3 orang atau 0,97\% dari total responden. Alumni yang saat ini sedang menempuh study lanjut S2, yaitu sebanyak 1 orang atau $0,32 \%$ dari total responden.dan sisanya adalah yang masih menganggur dikarenakan habis kontrak kerjanya atau sedang mancari pekerjaan yaitu sebesar $3,2 \%$.

Untuk alumni yang bekerja sebagai karyawan di perusahaan, meskipun tingkatannya rata-rata sebagai staf, tetapi posisi dan bagian yang digeluti bervariasi. Ada yang berada di bagian SDM, Marketing, Produksi, Humas, Keuangan bahkan IT. Alumni Jurusan Ekonomi dan Administrasi juga bekerja dibanyak jenis perusahaan, ada perusahaan manufaktur, perusahaan jasa perbankan, asuransi, dan perusahaan jasa lain. Satu hal yang menarik dari profil pekerjaan alumni yang secara khusus bekerja 
sebagai karyawan di perusahaan, banyak dari mereka yang posisi pekerjaannya berbeda dari latar belakang atau core kompetensi program studynya. Hal ini menunjukkan bahwa lapangan pekerjaan seorang lulusan Fakultas Ekonomi Universitas Negeri Jakarta sangat beragam. Gambaran lebih rinci berkaitan dengan profile pekerjaan alumni Fakultas Ekonomi UNJ disajikan dalam tabel profile pekerjaan alumni masing-masing Jurusan.

TABEL 4.2 Profile Pekerjaan Alumni

\begin{tabular}{|l|c|c|c|c|c|c|}
\hline \multicolumn{1}{|c|}{ JURUSAN } & GURU & KARYAWAN & WRAUSHA & $\begin{array}{c}\text { STUDY } \\
\text { S1 S2 }\end{array}$ & NGANGGUR & TOTAL \\
\hline $\begin{array}{l}\text { EKONOMI } \\
\text { ADMINISTRASI }\end{array}$ & 17 & 160 & 1 & 1 & 6 & 175 \\
\hline AKUNTANSI & $\cdot$ & 69 & $\cdot$ & $\cdot$ & 1 & 70 \\
\hline MANAJEMEN & 1 & 57 & 2 & $\cdot$ & 3 & 63 \\
\hline TOTAL & 18 & 286 & 3 & 1 & 10 & 308 \\
\hline $\begin{array}{l}\text { PERSENTASE } \\
(\%)\end{array}$ & $5,8 \%$ & $92,8 \%$ & $0,97 \%$ & $0.32 \%$ & $3,2 \%$ & 100 \\
\hline
\end{tabular}

\section{Profil Pekerjaan Alumni Jurusan Ekonomi Administrasi}

Menurut data yang kami peroleh, jika melihat lagi pada profile pekerjaan mereka secara rinci maka untuk jurusan Ekonomi dan Administrasi terdapat prosentase paling besar yaitu $19,4 \%$ alumninya pada level staf baik itu staf marketing, keuangan dll dan 19,4\% juga alumninya menjadi pegawai administrasi. Sedangkan prosentase sisanya $9,7 \%$ menjadi guru, 5,7\% menjadi teller, $4 \%$ menjadi customer service dan 3,4\% menjadi sekretaris dan marketing, sisanya alumni bekerja pada profile yang berbedabeda. Hal ini dapat dilihat pada tabel 4.3 di bawah ini.

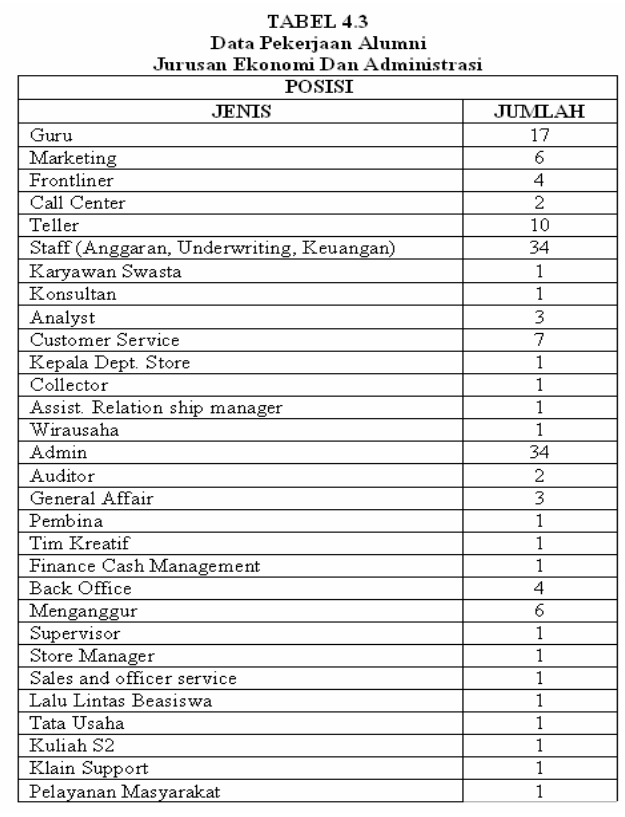

Profil Pekerjaan Alumni Jurusan Akuntansi

Menurut data yang kami peroleh, jika melihat lagi pada profile pekerjaan mereka secara rinci maka untuk jurusan Akuntansi tidak jauh berbeda dengan jurusan Ekonomi dan Administrasi dimana terdapat prosentase paling besar yaitu lebih dari setengahnya atau $62,9 \%$ alumninya juga pada level staf baik itu staf accounting, tax, marketing, keuangan, 10\% alumninya menjadi auditor, masingmasing sebagai internal audit, kabag accounting dan frontliner 
sebesar 4,3\%, sisanya alumni bekerja pada profile yang berbedabeda. Hal ini dapat dilihat pada tabel 4.4 di bawah ini.

TABEL 4.4

Data Pekerjaan Alumn Jurusan Akuntansi

\begin{tabular}{|c|c|}
\hline \multicolumn{2}{|l|}{ Jurusan Akuntansi } \\
\hline JENIS & JUМАН \\
\hline Menganggur & 1 \\
\hline Internal Audit & 3 \\
\hline Auditor & 7 \\
\hline Import Document Anayst & 1 \\
\hline Teller & 1 \\
\hline PR & 1 \\
\hline Reminding Billing & 1 \\
\hline Kasir & 1 \\
\hline Staff (Marketing, Ac ounting, Tax, Budgeting) & 44 \\
\hline Credit Manager & 1 \\
\hline Kuliah & 1 \\
\hline Kepala Bag. Acc & 3 \\
\hline Frontliner & 3 \\
\hline Cost Control & 1 \\
\hline Junior Consultant & 1 \\
\hline Syariah Funding Executive & 1 \\
\hline & 70 \\
\hline
\end{tabular}

Profile Pekerjaan Alumni Jurusan Manajemen

Menurut data yang kami peroleh, jika melihat lagi pada profile pekerjaan mereka secara rinci maka untuk jurusan Manajemen juga tidak jauh berbeda dengan jurusan Ekonomi dan Administrasi serta Akuntansi dimana terdapat prosentase paling besar yaitu $31,8 \%$ alumninya juga pada level staf baik itu staf purchasing, marketing, ekspor, 9,5\% alumninya menjadi operation admin, 8,2\% alumninya sebagai teller, 6,3\% sebagai customer service, sisanya alumni bekerja pada profile yang berbeda- beda. Hal ini dapat dilihat pada tabel 4.5 di bawah ini.

\begin{tabular}{|c|c|}
\hline \multirow{2}{*}{\multicolumn{2}{|c|}{$\begin{array}{c}\text { TABEL } 4.5 \\
\text { Data Pekerjaan Alumni } \\
\text { Jurusan Manajemen } \\
\text { POSISI }\end{array}$}} \\
\hline & \\
\hline JENIS & JUMLAH \\
\hline HRD & 1 \\
\hline Teller & 5 \\
\hline $\begin{array}{l}\text { Staff (Marketing, } \\
\text { Purchasing,Export) }\end{array}$ & 20 \\
\hline Assist. Officer & 1 \\
\hline Wirausaha & 2 \\
\hline Supply chain & 1 \\
\hline Menganggur & 3 \\
\hline Editor & 1 \\
\hline Sales Manager & 1 \\
\hline Transfer Agent & 1 \\
\hline Sekretaris & 1 \\
\hline Back office & 1 \\
\hline Validasi Data & 1 \\
\hline Distribusi & 1 \\
\hline Design Support & 3 \\
\hline Foreign Affair & 1 \\
\hline Pramuniaga & 1 \\
\hline Credit Analyst & 1 \\
\hline Account Officer & 1 \\
\hline Aria Supervisor & 1 \\
\hline \multirow{2}{*}{$\begin{array}{l}\text { Frontliner } \\
\text { Training Consultant }\end{array}$} & 2 \\
\hline & 1 \\
\hline Training Consultant & \\
\hline \multirow{2}{*}{ JENIS } & JUMLAH \\
\hline & 4 \\
\hline Operation admin & 6 \\
\hline
\end{tabular}

\section{Profile Pekerjaan Alumni Berdasarkan Program Studi}

Menurut data yang kami peroleh berdasarkan program studi maka untuk program studi Pendidikan Ekonomi terdapat $10,43 \%$ alumninya menjadi guru dan $86,9 \%$ alumninya menjadi karyawan dan 2,6\% yang belum bekerja. Untuk program studi Pendidikan Tata Niaga terdapat $12,5 \%$ yang menjadi guru, $85 \%$ menjadi karyawan 2,5\% yang berwirausaha. Untuk program studi S1 Manajemen terdapat 90,4\% menjadi karyawan, 3,2\% berwirausaha dan $6 \%$ yang belum 
bekerja. Untuk program studi D3 Pemasaran $80 \%$ menjadi karyawan dan $20 \%$ belum bekerja. Sedangkan program studi S1 akuntansi 97,51\% alumninya menjadi karyawan dan 2,5\% yang belum bekerja. Yang paling menarik adalah untuk program D3 Akuntansi 100\% alumninya bekerja menjadi karyawan. Data lengkap bisa dilihat di tabel 4.6 dibawah ini:

TABEL 4.6

Profil Pekerjaan Alurni Per Program Stud

\begin{tabular}{|c|c|c|c|c|c|c|}
\hline PROGRAM STUDI & GURU & KARYAWN & $\begin{array}{l}\text { WRA } \\
\text { USAHA }\end{array}$ & $\begin{array}{l}\text { STUDI } \\
\text { S1/\$2 }\end{array}$ & \begin{tabular}{|l|} 
BELUM \\
BEKERJA
\end{tabular} & TOTAL \\
\hline \begin{tabular}{|l|} 
PEND. EKONOMI \\
\end{tabular} & 12 & 100 & . & & 3 & 115 \\
\hline PEND TATA NIAGA & 5 & 24 & 1 & - & - & 30 \\
\hline \begin{tabular}{|l} 
D3 SEKERTARI \\
\end{tabular} & & 26 & . & 1 & 3 & 30 \\
\hline \begin{tabular}{|l|} 
PROGRAM STUDI \\
\end{tabular} & GURU & KARYAWN & $\begin{array}{l}\text { WIRA } \\
\text { USAHA }\end{array}$ & $\begin{array}{l}\text { STUDI } \\
\text { S1S2 }\end{array}$ & \begin{tabular}{|l} 
BELUM \\
BEKERJA
\end{tabular} & TOTAL \\
\hline SI MANAJIMMEN & 1 & 45 & 2 & - & - & 48 \\
\hline D3 PEMASARAN & - & 12 & 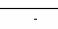 & - & 3 & 15 \\
\hline SI AKUNT ANSI & - & 39 & . & - & 1 & 40 \\
\hline D3 AKUNTANSI & - & 30 & . & - & - & 30 \\
\hline TOTAL & 18 & 276 & 3 & 1 & 10 & 308 \\
\hline
\end{tabular}

Gambaran lebih rinci berkaitan dengan profile pekerjaan berdasarkan program studi di Fakultas Ekonomi adalah sebagai berikut yang disajikan dalam tabel profile pekerjaan.
TABEL 4.7

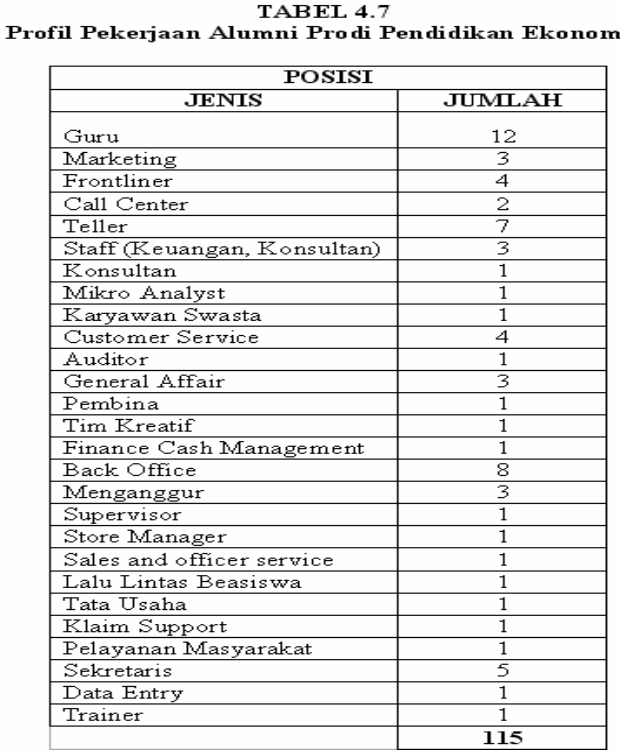

Profile pekerjaan Alumni Prodi Pendidikan Ekonomi

Menurut data yang kami peroleh, jika melihat lagi pada profile pekerjaan mereka secara rinci maka untuk Prodi Pendidikan Ekonomi terdapat profile pekerjaan yang cukup bervariasi baik dari level dan bidangnya, untuk prosentase paling besar yaitu $10,4 \%$ alumninya sebagai guru, $7 \%$ alumninya menjadi back office, $6,1 \%$ alumninya sebagai teller, $4,3 \%$ sebagai sekretaris, 3,5\% sebagai front liner dan sisanya alumni bekerja pada profile yang berbeda-beda. 
Profile Pekerjaan Alumni Prodi Tata Niaga

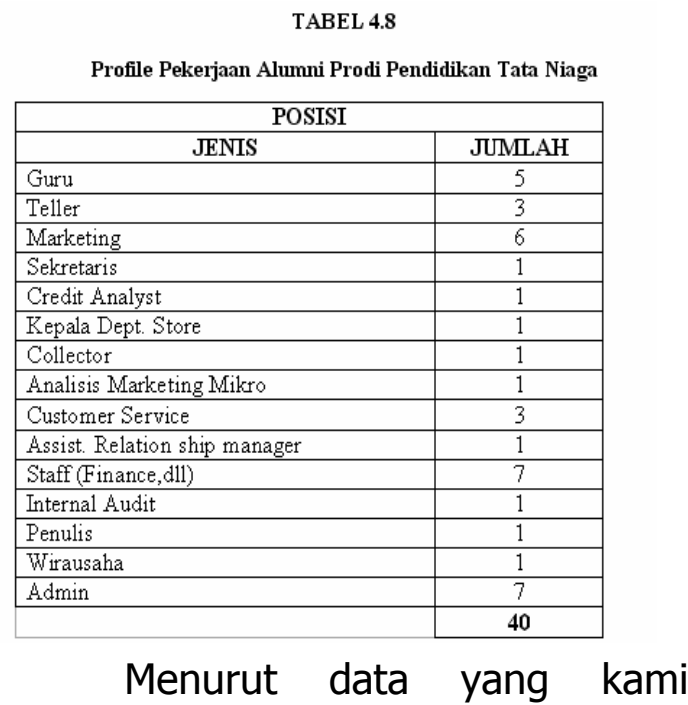

peroleh, jika melihat lagi pada profile pekerjaan mereka secara rinci maka untuk Prodi Pendidikan Tata Niaga terdapat profile pekerjaan yang cukup bervariasi baik dari level dan bidangnya, untuk prosentase paling besar yaitu $17,5 \%$ alumninya sebagai staf dan sebagai admin, $15 \%$ alumninya menjadi marketing, $12,5 \%$ alumninya sebagai guru, $7,5 \%$ sebagai teller dan customer service dan sisanya alumni bekerja pada profile yang berbeda-beda.
Profile pekerjaan alumni Prodi D3 Sekretari

Tabel 4.9

Profile Pekerjaan Alumni Prodi D3 Sekertari

\begin{tabular}{|l|c|}
\hline \multicolumn{2}{|c|}{ POSISI } \\
\hline JENIS & JMLAH \\
\hline Frontliner & 4 \\
\hline Customer Service & 1 \\
\hline Teller & 1 \\
\hline Staf (Admin, HRD) & 13 \\
\hline Marketing & 1 \\
\hline Belum bekerja & 3 \\
\hline Sekretaris & 5 \\
\hline Tata Usaha & 1 \\
\hline Kuliah & 1 \\
\hline \multicolumn{2}{|c|}{} \\
\cline { 2 - 2 }
\end{tabular}

Menurut data yang kami peroleh, jika melihat lagi pada profile pekerjaan mereka secara rinci maka untuk Prodi D3 Sekretari prosentase paling besar yaitu $43,3 \%$ alumninya sebagai staf, $16,7 \%$ alumninya menjadi sekretaris (dimana memang profesi ini yang dianggap sesuai dengan bidangnya), $\quad 13,3 \%$ alumninya sebagai front liner, dan sisanya alumni bekerja pada profile yang berbeda-beda.

\section{Profile pekerjaan alumni Prodi} S1 Manajemen

Menurut data yang kami peroleh, jika melihat lagi pada profile pekerjaan mereka secara rinci maka untuk Prodi S1 Manajemen terdapat profile pekerjaan yang sangat bervariasi baik dari level dan bidangnya, 
untuk prosentase paling besar yaitu $10,4 \%$ alumninya sebagai staf, $4,2 \%$ alumninya menjadi account executive, sedangkan sisanya masing-masing $\quad 2,1 \%$ alumninya bekerja pada profile yang berbedabeda seperti CSO, Guru, customer service, HRD, dll.

TABEL 4.10

Profile Pekerjaan Alumni Prodi S1 Manajemen

\begin{tabular}{|c|c|}
\hline \multicolumn{2}{|c|}{ POSISI } \\
\hline JENIS & JULAH \\
\hline Sales Engineering & 1 \\
\hline Assistant Supervisor & 1 \\
\hline Staff (Finance, Supliscm, Finance, Budgeting) & 5 \\
\hline Usher & 1 \\
\hline Auditor & 1 \\
\hline Account Payable & 1 \\
\hline Customer Service & 1 \\
\hline Being Collection & 1 \\
\hline Guru & 1 \\
\hline Bisnis Development & 1 \\
\hline Usaha Sendiri, Pimpinan & 1 \\
\hline Supervisor Marketing & 1 \\
\hline HRD & 1 \\
\hline Account Executive & 2 \\
\hline Tallent Artist & 1 \\
\hline Sekretaris Direksi & 1 \\
\hline Official Development Program & 1 \\
\hline Fasilitator Training & 1 \\
\hline CSO & 1 \\
\hline PHS Payment Administration & 1 \\
\hline & $\mathbf{4 8}$ \\
\hline &
\end{tabular}

\section{Profile pekerjaan alumni D3}

\section{Pemasaran}

Menurut data yang kami peroleh, jika melihat lagi pada profile pekerjaan mereka secara rinci maka untuk Prodi D3 Pemasaran terdapat profile pekerjaan yang cukup bervariasi baik dari level dan bidangnya dan tersebar secara merata, yaitu $26,7 \%$ alumninya sebagai administrasi baik administrasi marketing, administrasi collecting, $20 \%$ sebagai staff, sedangkan sisanya masing-masing $6,7 \%$ alumninya bekerja pada profile yang berbeda-beda seperti sekretari, front liner, dll.

\section{TABEL 4.11}

Profile Pekerjaan Alumni Prodi D3 Pemasaran

\begin{tabular}{|c|c|}
\hline \multicolumn{2}{|c|}{ POSISI } \\
\hline JENIS & JMLAH \\
\hline $\begin{array}{c}\text { Administrasi (Adm.Marketing, } \\
\text { Adm. Collecting, } \\
\text { Adm.PurchaseI }\end{array}$ & 4 \\
\hline Belum bekerja & 3 \\
\hline Staff (Staff Consultant) & 3 \\
\hline Sekretaris & 1 \\
\hline Front Liner & 1 \\
\hline Operator & 1 \\
\hline General Affair & 1 \\
\hline Call Center & 1 \\
\hline & $\mathbf{1 5}$ \\
\hline
\end{tabular}

\section{Profile pekerjaan alumni S1}

\section{Akuntansi}

TABEL 4.12

Profile Pekerjaan Alumni S1 Akuntansi

\begin{tabular}{|c|c|}
\hline \multicolumn{2}{|c|}{ POSISI } \\
\hline JENIS & JULAH \\
\hline Belum bekerja & 1 \\
\hline Tax Accounting & 1 \\
\hline Staff Pajak & 3 \\
\hline Senior Auditor & 5 \\
\hline Junior Auditor & 1 \\
\hline Junior Akuntan & 14 \\
\hline Auditor & 2 \\
\hline Pengelola Unit & 1 \\
\hline Accounting Staff & 6 \\
\hline Auditor Finance & 3 \\
\hline Keuangan & 1 \\
\hline MKS & 1 \\
\hline Staff Budget & 1 \\
\hline & $\mathbf{4 0}$ \\
\hline
\end{tabular}

Menurut data yang kami peroleh, jika melihat lagi pada profile pekerjaan mereka secara rinci maka untuk Prodi S1 Akuntasi terdapat profile pekerjaan yang 
cukup bervariasi baik dari level dan bidangnya, untuk prosentase paling besar yaitu 35\% alumninya sebagai junior akuntan (dimana memang sesuai dengan jurusan yang diambil), $15 \%$ alumninya menjadi staff accounting, $12,5 \%$ alumninya sebagai senior auditor, masingmasing 7,5\% sebagai staf pajak dan auditor finance, 5\% sebagai auditor dan sisanya alumni bekerja pada profile yang berbeda-beda.

\section{Profile Pekerjaan Alumni D3 Akuntansi}

Menurut data yang kami peroleh, jika melihat lagi pada profile pekerjaan mereka secara rinci maka untuk Prodi D3 Akuntansi terdapat profile pekerjaan yang cukup bervariasi baik dari level dan bidangnya, untuk prosentase paling besar yaitu 53,3\% alumninya sebagai staf keuangan, 30\% alumninya menjadi staf keuangan, $6,7 \%$ alumninya sebagai junior compliance, dan sisanya alumni bekerja pada profile yang berbedabeda.
TABEL 4.13

Profile Pekerjaan Alumni Prodi D3 Akuntansi

\begin{tabular}{|c|c|}
\hline \multicolumn{2}{|c|}{ POSISI } \\
\hline JENIS & JUMLAH \\
\hline Staff Keuangan & 16 \\
\hline Administrasi & 1 \\
\hline Accounting & 9 \\
\hline Teller & 1 \\
\hline Junior Compliance & 2 \\
\hline Staff Pajak & 1 \\
\hline & $\mathbf{3 0}$ \\
\hline
\end{tabular}

PROFILE TINGKAT GAJI

PERTAMA

Tingkat Gaji pertama

berdasarkan Jurusan

Tingkat gaji yang diterima oleh alumni Fakultas Ekonomi Universitas Negeri Jakarta bervariasi dari mulai nominal kurang dari 1 juta sampai lebih dari 4 juta.Tingkat gaji ini mengalami kenaikan dibandingkan tahun lalu. Rata-rata penghasilantahun ini berada di tingkat 2-3 juta. Alumni dengan penghasilan pertama 1-2 juta berjumlah 113 orang atau hampir 39,4\% dari total responden. Sedangkan Alumni dengan penghasilan pertama dengan gaji 2-3 juta berjumlah 122 orang atau hampir $42,5 \%$ dari total responden. Hal ini menunjukkan bahwa lulusan Fakultas Ekonomi Universitas Negeri Jakarta rata - rata bekerja dengan gaji di atas upah minimal regional yang ditetapkan oleh 
pemerintah. Bahkan ada 22 orang alumni yang pada saat pertama kali masuk penghasilannya mencapai lebih dari 3 juta atau 7,7 \% dari total responden.Sedangkan alumni yang penghasilannya di bawah 1 juta ada 14 orang, atau 4,9\% dari total responden. Data lebih lengkap mengenai profile tingkat penghasilan alumni dapat dilihat pada tabel 4.14.

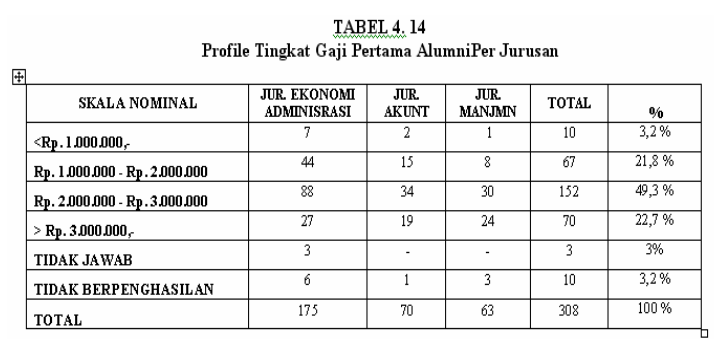

\section{Tingkat Gaji Pertama Alumni} berdasarkan Program Studi

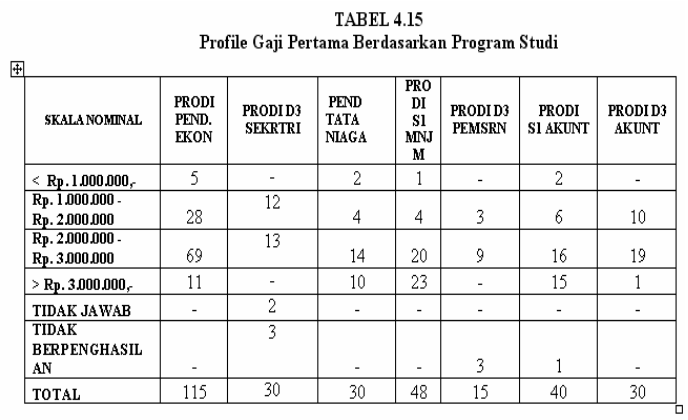

Berdasarkan tabel 4.15 diatas profile gaji pertama yang diterima alumni jika dideskripsikan berdasarkan program studi dan diprosentasekan adalah sebagai berikut: untuk prodi Pendidikan Ekonomi yang gaji pertamanya dibawah satu juta 4,3\%, yang gajinya 1 s/d 2 juta 24,3\%, yang gajinya 2 s/d 3 juta sebanyak $60 \%$ dan yang gajinya diatas 3 juta sebanyak 9,6\%.

Untuk prodi Pendidikan Tata Niaga yang gaji pertamanya dibawah 1 juta sebanyak 6,7\%, yang gajinya 1 s/d 2 juta sebanyak $13,3 \%$ dan yang gajinya 2 s/d 3 juta sebanyak 33,3\%.

Untuk prodi S1 Manajemen yang gajinya dibawah 1 juta sebanyak 2,1\%, yang gajinya antara 1 s/d 2 juta 8,3\%, yang gajinya 2 s/d 3 juta $41.7 \%$ dan yang diatas 3 juta sebanyak $48 \%$. Untuk prodi D3 Pemasaran yang gaji pertamanya dibawah 1 juta sebanyak $20 \%$, yang gajinya antara 2 s/d 3 juta 60\%. Untuk prodi S1 Akuntansi yang gajinya dibawah 1 juta 5\%, yang gajinya 1 s/d 2 juta sebanyak $15 \%$ yang gajinya antara 2 s/d 3 juta 40\% sedangkan yang diatas tiga juta sebanyak $37.5 \%$. Terakhir untuk prodi D3 Akuntansi yang gajinya antara 1 s/d 2 juta sebanyak 33,3\%, dan yang gajinya antara 2 s/d 3 juta sebanyak $63,3 \%$. 


\section{PROFILE LAMA WAKTU MENUNGGU}

Indikator berikut yang disajikan oleh peneliti untuk melihat kompetensi alumni Fakultas Ekonomi Universitas Negeri Jakarta adalah profile lama waktu menunggu untuk mendapatkan pekerjaan.

\section{Profile lama menunggu berdasarkan Jurusan}

Dari data yang ditampilkan dalam tabel 4.16 dapat disimpulkan bahwa, rata-rata alumni tidak membutuhkan waktu yang lama untuk mendapatkan pekerjaan. Meskipun ada 7 responden yang belum bekerja atau 2,52\% dari total responden, tetapi persentase terbesar sebanyak 43,89\% responden menjawab bahwa mereka hanya butuh waktu 0-6 bulan untuk mendapatkan pekerjaan. Tidak ada responden yang mengaku mereka butuh waktu lebih dari satu tahun untuk mendapatkan pekerjaan.Ini menunjukkan bahwa alumni Fakultas Ekonomi Universitas Negeri Jakarta, dapat bersaing di bursa tenaga kerja dan lebih baik dibandingkan tahun lalu.

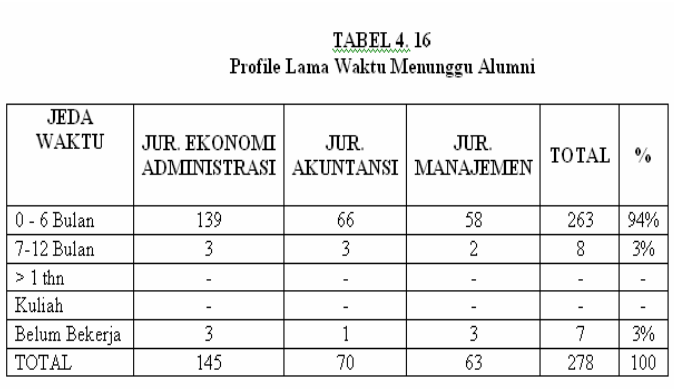

Profile lama menunggu berdasarkan Program Studi

Profile Lama Waktu Menunggu Ber dasarkan Program Studi

\begin{tabular}{|l|c|c|c|c|c|c|c|}
\hline $\begin{array}{c}\text { JEDA } \\
\text { WAKTU }\end{array}$ & $\begin{array}{c}\text { PRODI } \\
\text { PEND. } \\
\text { EKON }\end{array}$ & $\begin{array}{c}\text { PRODI } \\
\text { D3 } \\
\text { SEKRT } \\
\text { RI }\end{array}$ & $\begin{array}{c}\text { PROD } \\
\text { I } \\
\text { PEND } \\
\text { TATA } \\
\text { NIAG } \\
\text { A }\end{array}$ & $\begin{array}{c}\text { PRODI } \\
\text { S1 } \\
\text { MNJMN }\end{array}$ & $\begin{array}{c}\text { PRODI } \\
\text { D3 } \\
\text { PMASR } \\
\text { N }\end{array}$ & $\begin{array}{c}\text { PROD } \\
\text { I } \\
\text { S1 } \\
\text { AKUN } \\
\text { T }\end{array}$ & $\begin{array}{c}\text { PRODI } \\
\text { D3 } \\
\text { AKUNT }\end{array}$ \\
\hline 0 - 6 Bulan & 109 & 26 & 30 & 47 & 11 & 36 & 30 \\
\hline $7-12$ Bulan & 3 & 1 & - & 1 & 1 & 3 & - \\
\hline$>1$ thn & - & - & - & - & - & - & - \\
\hline Kuliah & - & - & - & - & - & - & - \\
\hline $\begin{array}{l}\text { Belum } \\
\text { Bekerja }\end{array}$ & 3 & 3 & - & - & 3 & 1 & - \\
\hline TOTAL & 115 & 30 & 30 & 48 & 15 & 40 & 30 \\
\hline
\end{tabular}

Berdasarkan tabel 4.17 diatas maka lama waktu menunggu untuk mendapatkan pekerjaan jika dikelompokkan berdasarkan program studi yang ada di Fakultas Ekonomi dapat dideskripsikan sebagai berikut: untuk prodi Pendidikan Ekonomi jumlah alumni dengan masa menunggu 0 s/d 6 bulan adalah sebanyak 94,8\%, antara $7 \mathrm{~s} / \mathrm{d} 12$ bulan sebanyak 2,6\% dan yang belum mendapatkan pekerjaan adalah sebanyak 2,6\%. Untuk prodi Pendidikan Tata Niaga jumlah alumni yang membutuhkan waktu 
menunggu antara $0 \mathrm{~s} / \mathrm{d} 6$ bulan sebanyak $100 \%$.

Untuk prodi D3 Sekretari yang membutuhkan waktu $0 \mathrm{~s} / \mathrm{d} 6$ bulan sebanyak $\quad 86,7 \%$, yang membutuhkan waktu antara 7 s/d 12 bulan sebanyak 3,3\% dan yang belum mendapatkan pekerjaan sebanyak 1\%. Untuk prodi S1 Manajemen yang membutuhkan waktu 0 s/d 6 bulan sebanyak $97,9 \%$, yang membutuhkan waktu antara 7 s/d 12 bulan sebanyak $2,1 \%$

Untuk prodi D3 Manajemen Pemasaran yang membutuhkan waktu 0 s/d 6 bulan sebanyak $73,3 \%$, yang membutuhkan waktu antara 7 s/d 12 bulan 6,7\% dan yag belum mendapatkan pekerjaan sebanyak 20\%. Untuk prodi S1 Akuntansi yang membutuhkan waktu antara 0 s/d 6 bulan sebanyak 90\%, antara 7 s/d 12 bulan sebanyak $7,5 \%$ dan yang belum mendapatkan pekerjaan adalah sebanyak 2,5\%. Terakhir untuk prodi D3 Akuntansi jumlah alumni yang membutuhkan waktu antara 0 s/d 6 bulan sebanyak $100 \%$.
PROFIL KESESUAIAN BIDANG PEKERJAAN ALUMNI

Profil Kesesuaian bidang pekerjaan berdasarkan Jurusan Indikator berikutnya adalah kesesuaian bidang pekerjaan alumni yang sedang digeluti para alumni dengan latar belakang pendidikannya, dari data yang ditampilkan dalam table 4.18

TABEL 4.18

TABEL 4.18
Kesesuaian Bidang Pekerjaan Alumni
\begin{tabular}{|c|c|c|c|c|c|}
\hline KSESUAIAN & $\begin{array}{c}\text { JUR EKONOMI } \\
\text { ADMINISTRASI }\end{array}$ & $\begin{array}{c}\text { JUR } \\
\text { AKINTANSI }\end{array}$ & $\begin{array}{c}\text { JUR } \\
\text { MANAJEMEN }\end{array}$ & TOTAL & $\%$ \\
\hline Sesuai & 87 & 61 & 42 & 190 & 69,3 \\
\hline Tidak Sesuai & 58 & 8 & 18 & 84 & 30,7 \\
\hline
\end{tabular}

Dapat disimpulkan bahwa rata-rata alumni Fakultas Ekonomi Universitas Negeri Jakarta sesuai bidang pekerjaannya dengan latar belakang pendidikannya. Terdapat $69,3 \%$ alumni Fakultas ekonomi yang bidang pekerjaannya sesuai dan ada sebanyak 30,7\% alumni yang tidak sesuai bidang pekerjaannya.

Profil Kesesuaian bidang pekerjaan menurut Program Studi

Jika dideskripsikan kesesuaian bidang pekerjaan alumni berdasarkan bidang pekerjaan menurut program studi maka berdasarkan tabel 4.19 dapat 
dideskripsikan

sebagai

berikut(bentuk kesesuaian diambil dari persepsi alumni yang disurvei):

Untuk prodi Pendidikan Ekonomi sebanyak 58,3\% alumni sesuai bidang pekerjaannya dan sisanya $41,7 \%$ tidak sesuai. Untuk prodi pendidikan Tata Niaga sebanyak $66,7 \%$ alumninya sesuai bidang pekerjaannya dan sisanya 33,3\% tidak sesuai. Untuk

program studi S1 Manajemen 73\% bidang pekerjaan alumni sesuai dan sisanya $27 \%$ tidak sesuai. Untuk prodi D3 Pemasaran 658,3\% bidang pekerjaan alumni sesuai dan sisanya $41,7 \%$ tidak sesuai.

Untuk program studi S1 Akuntansi $100 \%$ bidang pekerjaan alumni sesuai dan $0 \%$ tidak sesuai. Untuk prodi D3 Akuntansi 73,3\% bidang pekerjaan alumni sesuai dan sisanya $26,7 \%$ tidak sesuai.

Kesesuaian Bidang Pekerjaan Alumni Menurut Program Stud

\begin{tabular}{|l|c|c|c|c|c|c|c|}
\hline KSESUAIAN & $\begin{array}{c}\text { PRODI } \\
\text { PEND. } \\
\text { EKON }\end{array}$ & $\begin{array}{c}\text { PRODI } \\
\text { D3 } \\
\text { SKRTARI }\end{array}$ & $\begin{array}{c}\text { PRODI } \\
\text { PEND } \\
\text { TATA } \\
\text { NAAGA }\end{array}$ & $\begin{array}{l}\text { PRODI SI } \\
\text { MANJMN }\end{array}$ & $\begin{array}{c}\text { PRODI } \\
\text { D3 } \\
\text { PEMSRN }\end{array}$ & $\begin{array}{c}\text { PRODI } \\
\text { SI } \\
\text { AKUNT }\end{array}$ & $\begin{array}{c}\text { PRODI } \\
\text { D3 } \\
\text { AKUNT }\end{array}$ \\
\hline SESUAI & 67 & 17 & 20 & 35 & 7 & 39 & 22 \\
\hline $\begin{array}{l}\text { TIDAK } \\
\text { SESUAI }\end{array}$ & 48 & 11 & 10 & 13 & 5 & - & 8 \\
\hline TOTAL & 115 & 28 & 30 & 48 & 12 & 39 & 30 \\
\hline
\end{tabular}

\section{Profil Persepsi Perusahaan} Terhadap Kemampuan Alumni

Indikator terakhir adalah persepsi perusahaan terhadap kemampuan alumni, tujuan dari suatu perguruan tinggi dalam hal ini fakultas adalah mencetak Iulusan yang mempunyai kompetensi sesuai dengan yang diperlukan dunia kerja, yang merupakan kombinasi dari pengetahuan, keterampilan, dan sikap yang menyumbang pada efektivitas seseorang dan semua hal tersebut diperlukan seseorang untuk bekerja secara efektif dalam berbagai jenis pekerjaan dan berbagai instansi. Kompetensi seseorang sebenarnya terdiri dari hard competencies/ hard skill dan soft competencies/ soft skill.

BAN-PT menjabarkan adanya tujuh macam kompetensi yang merupakan kombinasi antara hard skills dan soft skills yang perlu dimiliki lulusan perguruan tinggi di Indonesia, yaitu: 1) Integritas (etika dan moral); 2) Keahlian berdasarkan bidang ilmu (profesionalisme); 3) Bahasa Inggris; 4) Pengembangan diri; 5) Komunikasi; 6) Kerjasama tim; dan 7) Penggunaan Teknologi Informasi. Berpedomankan 7 kompetensi yang dicanangkan dalam BAN-PT, maka pada tracer study ini melihat pada sejumlah kualifikasi yang perlu dimiliki para lulusannya, yaitu: 
TABEL 4.20

Persepsi Perusahaan Terhadap Kemampuan Alumni

\begin{tabular}{|c|c|c|c|c|c|}
\hline No & ITEM PERTANYAAN & $\begin{array}{c}\text { SANGAT } \\
\text { BAIK } \\
\text { Sal }\end{array}$ & BAIK & $\begin{array}{c}\text { KURANG } \\
\text { BAIK }\end{array}$ & $\begin{array}{c}\text { TDAK } \\
\text { BAIK }\end{array}$ \\
\hline 1 & $\begin{array}{l}\text { Bagaimanakah integritas Alumni FE } \\
\text { UNJ }\end{array}$ & 4 & 16 & & \\
\hline 2 & $\begin{array}{l}\text { Bagaimana Etika dan Moral Alumni } \\
\text { FE UNJ }\end{array}$ & 4 & 16 & & \\
\hline 3 & $\begin{array}{l}\text { Bagaimana Profesionalisme Alumni } \\
\text { FE UNJ }\end{array}$ & & 20 & & \\
\hline 4 & $\begin{array}{l}\text { Bagaimana Penguasaan Bahasa } \\
\text { Inggris alumni FE UNJ }\end{array}$ & 8 & 12 & & \\
\hline 5 & $\begin{array}{l}\text { Bagaimana Penguasaan IT alumni FE } \\
\text { UNJ }\end{array}$ & 4 & 16 & & \\
\hline 6 & $\begin{array}{l}\text { Bagaimana kemampuan Komunikasi } \\
\text { alumni FE UNJ }\end{array}$ & 6 & 14 & & \\
\hline 7 & $\begin{array}{l}\text { Bagaimana kemampuan kerjasama } \\
\text { TMM alumni FE UNJ }\end{array}$ & 4 & 16 & & \\
\hline \multirow[t]{3}{*}{8} & $\begin{array}{l}\text { Bagaimana kemampuan } \\
\text { pengembangan diri alumni FE UNJ }\end{array}$ & 10 & 10 & & \\
\hline & Total & 40 & 120 & & \\
\hline & Prosentase Keseluruhan & $25 \%$ & $75 \%$ & $0 \%$ & $0 \%$ \\
\hline
\end{tabular}

Dari tabel 4.20 dapat dikatakan bahwa rata-rata kemampuan alumni Fakultas Ekonomi UNJ menurut persepsi perusahaan pemberi kerja adalah baik, hal ini dibuktikan dengan prosentase secara keseluruhan dari item pertanyaan adalah sebanyak 25 $\%$ menyatakan kemampuan alumni sangat baik dan $75 \%$ kemampuan alumni dianggap baik.

Namun jika digambarkan lebih rinci berdasarkan masing-masing item pertanyaan, maka untuk kategori integritas alumni maka 20 $\%$ persepsi perusahaan menyatakan sangat baik, dan $80 \%$ menyatakan baik. Berdasarkan kategori etika dan moral maka $20 \%$ menyatakan sangat baik dan $80 \%$ menyatakan baik. Berdasarkan kategori profesionalisme alumni maka $100 \%$ menyatakan baik. lalu berdasarkan penguasaan bahasa inggris maka $10 \%$ menyatakan sangat baik, $90 \%$ perusahaan menyatakan baik. lalu berdasarkan

penguasaan

IT(Teknologi Informasi) maka 20\% perusahaan menyatakan sangat baik dan 80 persen menyatakan baik. Kemudian berdasarkan indikator kemampuan komunikasi maka 30\% menyatakan alumni sangat baik dan $70 \%$ menyatakan baik. Kemampuan kerjasama Tim $20 \%$ perusahaan menyatakan sangat baik, $80 \%$ menyatakan baik. Terakhir berdasarkan kemampuan pengembangan diri alumni maka $50 \%$ menyatakan sangat baik dan $50 \%$ menyatakan baik

\section{PERSEPSI ALUMNI TERHADAP LAYANAN KEMAHASISWAAN}

Dalam rangka perbaikan ke segala aspek yang berkaitan dengan Fakultas baik itu dalam hal pembelajaran, kompetensi lulusan, termasuk hal pemberian layanan kepada mahasiswa. Pelayanan mahasiswa diberikan dalam bentuk layanan informasi, bimbingan akademik, administrasi akademik, perpustakaan, dll. Layanan ini dimaksudkan untuk membantu mahasiswa mengatasi masalah akademik dan administrasi akademik yang dihadapi selama belajar di Fakultas Ekonomi UNJ. Pada tracer study ini melihat persepsi alumni pada layanan 
administrasi kemahasiswaan, layanan beasiswa serta kepuasan mahasiswa terhadap ormawaormawa yang ada di jurusan dan fakultas.

Maka indikator berikutnya yang dianggap perlu untuk perbaikan pelayanan adalah persepsi alumni terhadap layanan bidang kemahasiswaan, dari data yang diperoleh dapat dideskripsikan bahwa $0,11 \%$ alumni menyatakan layanan kemahasiswaan sangat baik, $33,9 \%$ alumni menyatakan layanan kemahasiswaan baik dan 58,9\% menyatakan cukup baik dan 7,9\% menyatakan kurang baik.

Jika dideskripsikan lebih rinci tentang layanan kemahasiswaan yaitu layanan administrasi kemahasiswaan dinyatakan baik sebanyak $27 \%$ oleh alumni, dinyatakan cukup baik $53 \%$ dan dinyatakan kurang baik sebanyak 19\%. Untuk layanan beasiswa $30,8 \%$ alumni menyatakan baik, $57,8 \%$ alumni menyatakan beasiswa cukup baik dan $6 \quad \%$ yang menyatakan kurang baik.

Untuk kepuasan terhadap kegiatan ormawa $34 \%$ alumni menyatakan baik lalu 33,1\% alumni menyatakan cukup baik dan 4,3\% yang menyatakan kurang baik. Jika mengacu pada pendapat alumni terhadap layanan kemahasiswaan maka masih terlihat beberapa persen walaupun rendah prosentasenya bahwa pelayanan terhadap mahasiswa masih kurang baik. Hal ini perlu ditindaklanjuti pihak fakultas untuk memperbaiki fasilitas layanan baik dari sarana prasarana maupun personelnya.

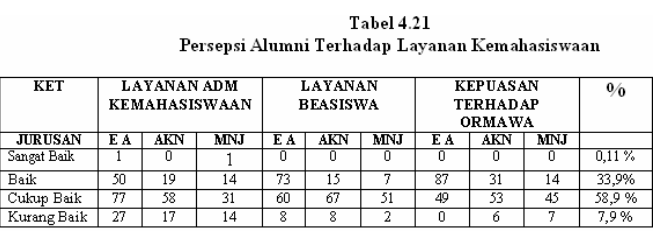

\section{KESULITAN YANG KADANG DIHADAPI ALUMNI DALAM BEKERJA}

Berkaitan dengan masih adanya kesulitan yang dihadapi oleh alumni pada saat mereka bekerja, pada penelitian ini, alumni juga diminta untuk memberikan saran, apa yang harus dilakukan oleh Fakultas Ekonomi untuk menjembatani kesulitan yang mereka alami, sehingga ke depan alumni yang lain tidak mengalami kesulitan pada hal yang sama. Dan dari jawaban responden ada beberapa point yang disarankan oleh mereka:

a. Mengembangkan materi-materi hard dan soft skill yang bisa menunjang pengembangan 
ketrampilan mahasiswa. Seperti Bahasa Inggris, komputer, komunikasi, kepribadian,peningkatan karakter dll.

b. Lebih banyak memberikan materi dalam bentuk praktek kerja yang sesuai dengan kebutuhan pasar saat ini.

c. Waktu Praktek Kerja Lapangan yang lebih lama.

d. Sering mengadakan kunjungan ke perusahaan, agar mahasiswa lebih mengenal dunia kerja.

e. Lebih banyak memberikan info lowongan kerja kepada alumni

f. Lebih meningkatkan matakuliah inti

g. Meningkatkan dan memperbaiki kurikulum sesuai dengan kebutuhan dunia kerja atau KKNI (Kerangka Kualifikasi Nasional Indonesia)

h. Lebih ditingkatkan peran CDC sebagai agen pemberi lowongan kerja dan CDC memiliki hubungan ke banyak lembaga pendidikan serta dunia industri.

\section{Keterbatasan Penelitian}

1. Tracer study baru dilakukan tiga kali di Fakultas Ekonomi Universitas Negeri Jakarta, sehingga masih banyak alumni yang tidak perhatian dengan program tracer, sehingga mereka enggan berpartisipasi.

2. Kesulitan dalam mendatangi dan mendapatkan perusahaan tempat alumni bekerja yang bersedia berpartisipasi sehingga perusahaan yang terjaring untuk mengetahui persepsi alumni jumlahnya sedikit.

\section{KESIMPULAN DAN SARAN Kesimpulan}

1. Penelitian ini merupakan studi kualitatif yang bertujuan untuk mengetahui kompetensi lulusan FE UNJ dari semua jurusan baik jurusan Ekonomi dan Administrasi jurusan Akuntansi maupun jurusan Manajemen berdasarkan profil mengenai waktu tunggu bekerja, kesesuaian bidang pekerjaa,profil posisi pekerjaan saat ini gaji awal dan persepsi perusahaan tentang kemampuan alumni.

2. Berdasarkan bidang pekerjaan, dapat disimpulkan bahwa meskipun alumni Fakultas Ekonomi yang terbanyak berasal dari Jurusan Ekonomi dan Administrasi Fakultas Ekonomi UNJ bergelar S.Pd, akan tetapi pada dasarnya mereka memiliki peluang untuk bekerja tidak 
hanya pada posisi guru, tapi mereka juga punya kompetensi untuk bekerja di bidang lain, sebagai karyawan perusahaan, baik perusahaan jasa maupun perusahaan manufaktur. Hal ini terbukti dari data yang tersaji bahwa alumni yang bekerja di tingkat Fakultas sebagai guru $5,8 \%$ dan yang menjadi karyawan $92,8 \%$, sisanya adalah $0,32 \%$ yang melanjutkan kuliah $\mathrm{S} 1 / \mathrm{S} 2,0,11 \%$ masih menganggur karena berhenti untuk mendapatkan pekerjaan lebih baik dan $0,97 \%$ yang menjadi wirausahawan.

3. Berdasarkan profile lama tunggu alumni untuk mendapatkan pekerjaan, dapat disimpulkan bahwa alumni hanya membutuhkan waktu kurang dari 6 bulan untuk mendapatkan pekerjaan yaitu sebanyak $94 \%$ alumni. Ini membuktikan bahwa alumni dapat bersaing di bursa tenaga kerja.

4. Tingkat gaji yang diterima alumni pada saat pertama kali mereka bekerja juga bervariasi, yaitu antara 2-3 juta sebanyak $49 \%$ dan $22,7 \%$ yang gajinya diatas 3 juta. Ini menunjukkan bahwa dari indikator gaji pertama yang diterima, alumni memiliki standar gaji yang memadai, lebih besar dari standar UMR yang ditetapkan pemerintah.

5. Kesulitan-kesulitan yang dihadapi oleh alumni dalam bekerja, lebih didominasi oleh kurangnya bekal ketrampilan mereka baik hard maupun soft skill dalam mempersiapkan diri masuk ke dunia kerja.

\section{Saran}

1. Berdasarkan data profil pekerjaan diketahui bahwa 86 persen lulusan FakultasEkonomi UNJ bekerja diperusahaan. Oleh karena itu FE UNJ melalui Career Development Center (CDC) perlu mengembangkan kerjasama lebih luas baik dengan lembaga pendidikan dan dinas pendidikan kota maupun dengan perusahaan yang bergerak di berbagai bidang.

2. Berdasarkan hasil kumpulan saran yang diberikan alumni, para alumni meminta agar mata kuliah yang berkaitan dengan IT (teknologi Informasi) ditingkatkan baik dalam hal update software nya maupun update pembelajarannya juga bimbingan dari dosen pengampu selain itu mereka 
juga meminta diperbanyak pelatihan pengembangan IT diluar perkuliahan.

3. Para alumni juga meminta agar pembekalan bahasa inggris lebih ditingkatkan baik dengan memperbanyak bahan dan pengajaran berbahasa inggris ditiap matakuliah maupun dengan banyak memberikan peluang pelatihan bahasa inggris.

4. Perlu ditinjau kembali kurikulum yang berkaitan dengan hard dan soft skill pada masing-masing prosram studi sesuai kebutuhan stakeholders saat ini.

5. Untuk keberlanjutan data dan informasi, data dan laporan hasil tracer study sebaiknya diintegrasikan oleh BAAK dalam Sistem Informasi Manajemen Fakultas Ekonomi. Untuk memenuhi kebutuhan pihak eksternal, laporan tracer study disampaikan dalam website $\mathrm{FE}$ UNJ.

6. Pada setiap akhir tahun akademik, pimpinan fakultas melalui CDC FE UNJ membentuk dan menugaskan Tim Tracer Study yang memulai tugas dengan meninjau ulang kuisioner Tracer Study dan mempertimbangkan saran dari laporan tahun sebelumnya.
Dengan demikian, materi kuisioner akan sesuai lingkup dan tujuan tracer study, yaitu bukan hanya untuk memperoleh informasi dari lulusan namun juga pengguna lulusan (stakeholders).

7. Verifikasi data lulusan dilakukan untuk validasi data secara acak sesuai keperluan juga dilakukan melalui website. Dengan caraon line secara lebih efektif dan mengoptimalkan peranan website FE UNJ diharapkan akan diperoleh data terkini yang akurat.

8. Perbaikan sistem database lulusan dan orangtuanya diperlukan agar numerator terlatih juga dapat mendata lulusan via telpon atau datang langsung ke alamat lulusan, terutama bagi responden yang tidak bisa mengakses internet.

9. Perkembangan profil lulusan dipantau melalui data time series yaitu menampilkan informasi profil lulusan tahun yang bersangkutan dan profil tahun-tahun sebelumnya.

10. Perlu ditindaklanjuti oleh pihak fakultas untuk memperbaiki fasilitas layanan baik dari sarana prasarana maupun personelnya. 
11. Sosialisasi hasil tracer study kepada berbagai pihak untuk memenuhi kebutuhan internal (pimpinan, pengambil keputusan dan sivitas akademika) dalam kaitannya dengan peningkatan mutu pendidikan berkelanjutan serta pihak eksternal (pengguna) dalam kaitannya dengan kebutuhannya sebagai user.

\section{DAFTAR PUSTAKA}

Anonymous. 2003. Higher Education Long Term Strategy. Direktorat Jenderal Pendidikan Tinggi. Jakarta.

Anonymous. 2003. Pedoman Penjaminan Mutu DIKTI. Direktorat Jenderal Pendidikan Tinggi. Jakarta.

Anonymous. 2003. Sistem Pendidikan Nasional.UU No.20/2003.Jakarta.

www. kopertis3.or.id 